\title{
Morphological Characters and Distribution of the Rice Root Aphids in West Java, Indonesia
}

\author{
Yani Maharani ${ }^{1 *}$, Harleni ${ }^{2}$, Purnama Hidayat ${ }^{3}$ \\ ${ }^{1}$ Department of Plant Pests and Diseases, Faculty of Agriculture, Padjadjaran University (UNPAD), Bandung, West Java \\ 45363 Indonesia \\ ${ }^{2}$ Alumnus of Entomology Program, IPB University, Bogor, West Java 16680 Indonesia \\ ${ }^{3}$ Department of Plant Protection, Faculty of Agriculture, IPB University, Bogor, West Java 16680 Indonesia \\ *Corresponding author.Email: yani.maharani@unpad.ac.id
}

\begin{abstract}
Information on the rice root aphids in Indonesia relatively little is known. A survey to collect the root aphids on some rice varieties was conducted in 2014-2015 in West Java Province, Indonesia. The collected specimens were carried to the laboratory for further morphological character observation and species identification. There were two aphids identified as Rhopalosiphum rufiabdominale (Sasaki) and Tetraneura nigriabdominalis (Sasaki) collected from rice varieties of Ciherang, IR-64, Cisadane and Rojolele. The rice root aphid $R$. rufiabdominale is oval-shaped body, reddish or greenish brown body colours, body length of 2.0-2.6 mm, antennae 5 segmented with antennal hairs long, antennal tubercle not clearly visible and terminal process more than 3 times longer than base, femur and siphunculi are dark brown or black, cauda shorter and darker than siphunculi. While $T$. nigriabdominalis has a body colour of red or brownish red and body like gall. Body length is 1.4-2.3 mm, the antenna terminal shorter than base antenna, the legs short, siphunculi like ring or pore shaped, and body hairs long. Both root rice aphids were found in these nine districts of the rice central production in Bandung, Bogor, Cianjur, Cirebon, Garut, Karawang, Kuningan, Sukabumi and Tasikmalaya. Rhopalosiphum rufiabdominale was collected from difference altitudes from 12 to $1.438 \mathrm{~m}$ above sea level (asl), while T. nigriabdominalis was collected from area below $1.000 \mathrm{~m}$ a.s.l. The results of this study indicate that both $R$. rufiabdominale and $T$. nigriabdominalis have a wide range of host rice varieties and vertical distribution from low land to high land.
\end{abstract}

Keywords: aphids, identification, paddy, Rhopalosiphum rufiabdominale, Tetraneura nigriabdominalis

\section{INTRODUCTION}

Rhopalosiphum rufiabdominale (Sasaki) and Tetraneura nigriabdominalis (Sasaki) (Hemiptera: Aphididae) are species of aphid which live in plants roots. Both species of aphid live in the rice roots or other Poaceae $[1,2]$. The first existence of $R$. rufiabdominale in Indonesia discovered by van der Goot on Calendula officinalis plants in Malang [3]. At that time, this species of aphid had not yet been discovered at the roots of any plants.

The first recorded species $T$. nigriabdominalis on plants roots by van der Goot. It was found on Poa root in Salatiga and rice root in Bogor [4]. T. nigriabdominalis has a wide distribution i.e. Africa, America, Australia, Bangladesh, Fiji, Indonesia, Italy, Japan, Korea, Laos, Malaysia, Nepal, New Zealand, Pakistan, Philippines, Sri Lanka, Slovenia, and Tonga [5-8]. The information on the rice root aphids in Indonesia is a unclear, especially aphids distribution. This study aims are to recognize the morphological character and distribution of two species aphid rice root in West Java. The results of this study provides basic information in taxonomy and insect biology, especially information on aphid's species in Indonesia.

\subsection{Materials and Methods}

The aphid samples collected from rice varieties of Ciherang, IR-64, Cisadane and Rojolele from nine districts of the central rice production in West Java, Indonesia. The sampling locations covered areas of Bandung, Bogor, Cianjur, Cirebon, Garut, Karawang, Kuningan, Sukabumi and Tasikmalaya (Figure 1). The samples were taken as much as $20 \%$ of total rice clumps in the rice field. Aphids on the root was taken by pulling the rice plants, and then the root rice was cut up to $\pm 15 \mathrm{~cm}$, and all sample put into a container or cup. The identification of aphids was carried out in the Laboratory of Insect Biosystematics, Department of Plant Protection, Faculty of Agriculture, IPB University, West Java, Indonesia. The aphid specimens, were collected by brush directly from 


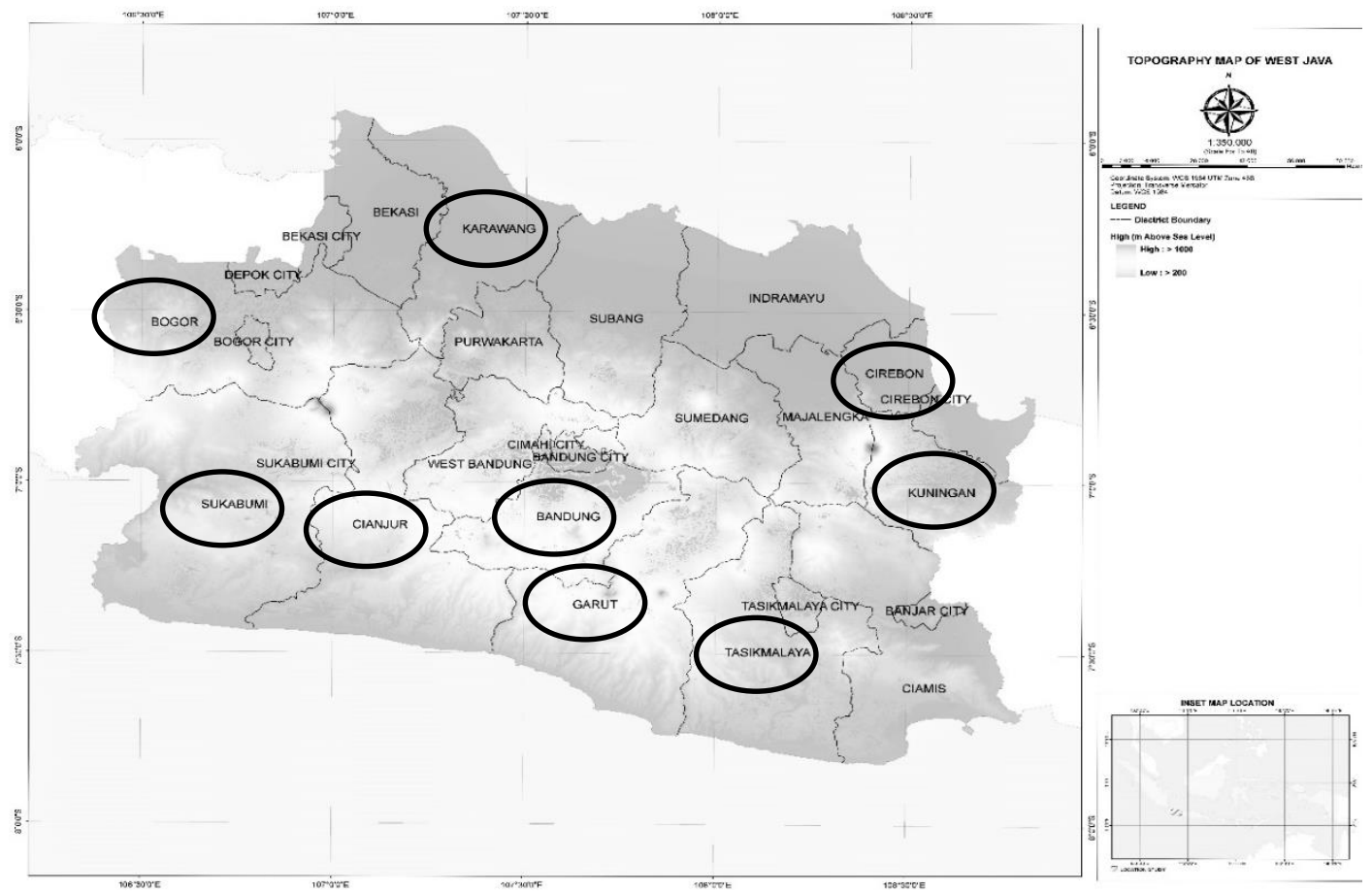

Figure 1 Aphid sampling locations in West Java, Indonesia.

the plants. Microscope preparation of the aphids was based on the method of Blackman and Eastop [9]. Adult specimens were mounted on microscope slides in Canada Balsam. Identification of aphids was carried out under an Olympus CX21 stereo microscope with images captured using Dino Capture software, and also under LEICA M205C microscopes. The species were identified based on morphological features. The identification of aphids was performed using several books published by van der Goot [10], Noordam [4], as well as Blackman and Eastop [9, 11]. In this research, the aphid population was counted on each rice plant phase, i.e. vegetative and generative phase.

\subsection{Our Contribution}

This paper presents basic information about the aphid's rice roots morphology and its distribution which is not widely known by others. This research also present paddy varieties that are most infested by two aphids species in the roots, which are the most widely grown varieties in Indonesia, especially West Java.

\subsection{Paper Structure}

The rest of the paper is organized as follows. Section 2 introduces the preliminaries used in this paper, information about host plants two rice root aphids in Indonesia and the world. Section 3 presents aphids collected from rice varieties in West Java. The taxonomy and systematic, morphological characters and distribution two of aphids in Section 4. Section 5 develops aphid population abundance in rice varieties. Section 6 concludes the paper and presents direction for future research.

\section{RESULTS AND DISCUSSION}

The rice root aphids, Rhopalosiphum rufiabdominale (Sasaki) and Tetraneura nigriabdominalis (Sasaki) were found in all nine districts of the rice central production in West Java. Both of these aphids found on three rice varieties, i.e Ciherang, IR-64, and Rojolele varieties. The results of this study indicate that both $R$. rufiabdominale and $T$. nigriabdominalis have a wide range of host rice varieties and vertical distribution from low land to high land. $R$. rufiabdominale was collected from difference altitudes from 12 to $1438 \mathrm{~m}$ a.s.1, while $T$. nigriabdominalis was collected from area below 1000 m.a.s.l. (Table 1). 
Table 1 Aphid species found on several rice varieties in West Java

\begin{tabular}{|c|c|c|c|c|}
\hline \multirow[b]{2}{*}{ Location } & \multicolumn{2}{|c|}{ Aphid Species } & \multirow[b]{2}{*}{ Rice Varieties } & \multirow{2}{*}{$\begin{array}{l}\text { Altitude } \\
\text { (m.a.s.l.) }\end{array}$} \\
\hline & $\begin{array}{l}\text { Rhopalosiphum } \\
\text { rufiabdominale }\end{array}$ & $\begin{array}{c}\text { Tetraneura } \\
\text { nigriabdominalis }\end{array}$ & & \\
\hline Bandung & + & - & Ciherang & 1,438 \\
\hline Bogor & + & + & Ciherang, IR-64 & $262-633$ \\
\hline Cianjur & + & + & Ciherang & $292-921$ \\
\hline Cirebon & + & + & Ciherang & 12 \\
\hline Garut & + & + & Ciherang, Rojolele, Cisadane & 600 \\
\hline Karawang & + & + & Ciherang & 145 \\
\hline Kuningan & + & + & Ciherang & 870 \\
\hline Sukabumi & + & - & Ciherang & 1029 \\
\hline Tasikmalaya & + & + & Ciherang, IR-64 & 388 \\
\hline
\end{tabular}

The taxonomy and systematic of the two aphids reference to Favret [12]. The morphological characteristics and systematic of the two aphids species were follows:

Rhopalosiphum rufiabdominale (Sasaki, 1899)

Tribe : Aphidini

Genus : Rhopalosiphum Koch, 1854

Common : Rice root aphid

name

Synonim : Cerosipha californica (Essig, 1944); Rhopalosiphum fucanoi Moritsu 1947; Rhopalosiphum gnaphalii Tissot, 1933; Anuraphis mume (Hori, 1927); Yamataphis oryzae (Matsumura, 1917); Yamataphis papaveri (Takahashi, 1921); Pseudocerosipha pruni Shinji 1932; Aresha setigera (Blanchard, 1939); Aresha shelkovnikovi (Mordvilko, 1921); Siphocoryne splendens (Theobald, 1915); Rhopalosiphum subterraneum Mason, 1937.

Description : Oval-shaped body, reddish or greenish brown body colours, body length of 2.0$2.6 \mathrm{~mm}$ (Figure 2a). Eyes distinctly reddish. The microscope preparat $R$. rufiabdominale can see on Figure $2 b$. Antennae 5 segmented with antennal hairs long. Antennal tubercle not clearly visible (Figure $2 \mathrm{c}$ ) and terminal process more than 3 times longer than base (Figure 2d). Femur femur and siphunculi are dark brown or black. cauda shorter and darker than siphunculi (Figure 2e).

Tetraneura nigriabdominalis (Sasaki, 1899)

Tribe : Eriosomatini

Genus : : Tetraneura Hartig, 1841

Subgenus : Tetraneurella Hille Ris Lambers, 1970

Synonim : Tetraneura akinire Sasaki, 1904; Mimeuria graminiradicis (Zhang, 1992); Dryopeia hirsuta (Baker, 1921); Tetraneura oryzae Van Heurn 1923; Pemphigus agrimoniae (Shinji, 1924).

Description : Imagoes body colour of red or brownish red and body like gall (Figure 3a). Eyes distinctly dark red-brownish. The microscope preparat $T$. nigriabdominalis can see on Figure 3b. Body length is 1.4$2.3 \mathrm{~mm}$. The antenna terminal shorter than base antenna (Figure 3c). The legs and antennal segment shorter than another aphids species. Siphunculi like ring or pore shaped (Figure 3d), and body hairs long. 

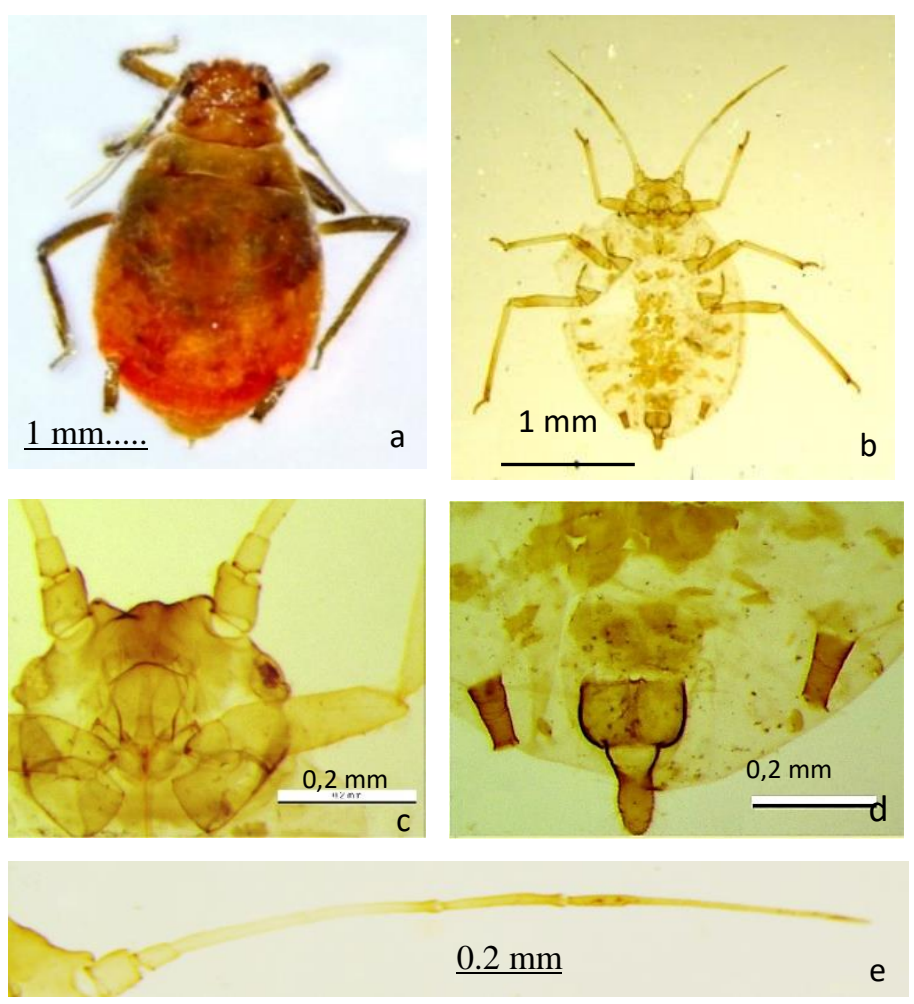

Figure 2 Rhopalosiphum rufiabdominale. (a) Adult, (b) microscope preparat (ventral), (c) antenal tubercle, (d) siphunculi and cauda, (e) antennae

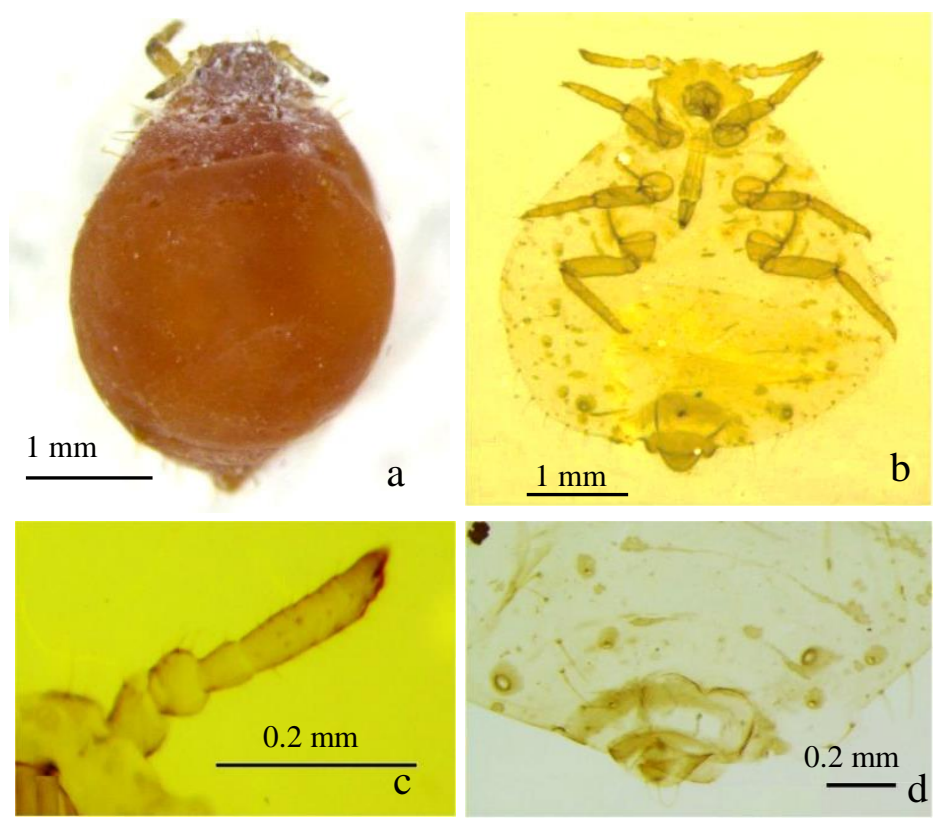

Figure 3 Tetraneura nigriabdominalis. (a) Adult, (b) microscope preparat (ventral), (c) antennae, (d) siphunculi and cauda 
Table 2 Aphid population on root rice plants

\begin{tabular}{|c|c|c|c|c|c|}
\hline \multirow{3}{*}{ Location } & \multicolumn{4}{|c|}{ Phase } & \multirow{3}{*}{$\begin{array}{c}\text { Aphids } \\
\text { position on } \\
\text { root (cm from } \\
\text { base stem) }\end{array}$} \\
\hline & \multicolumn{2}{|c|}{ Vegetative } & \multicolumn{2}{|c|}{ Generative } & \\
\hline & R. rufiabdoominale & T. nigriabdominalis & R. rufiabdoominale & T. nigriabdominalis & \\
\hline Bandung & 0 & 70 & 0 & 16 & $5-8$ \\
\hline Bogor & 242 & 16 & 73 & 145 & $3-9$ \\
\hline Cianjur & 138 & 114 & 60 & 171 & $2-4$ \\
\hline Cirebon & 304 & 23 & 8 & 0 & $2-3$ \\
\hline Garut & 67 & 86 & 2 & 6 & $3-4$ \\
\hline Karawang & 10 & 8 & 2 & 37 & $4-5$ \\
\hline Kuningan & 10 & 19 & 67 & 5 & $9-10$ \\
\hline Sukabumi & 0 & 7 & 0 & 177 & $8-9$ \\
\hline Tasikmalaya & 67 & 3 & 25 & 88 & $3-5$ \\
\hline
\end{tabular}

The existence of aphids in rice roots can be found from the mid vegetative phase to the last generative phase. Aphids live in a colony of rice roots in the vicinity of about $2-10 \mathrm{~cm}$ from the base of the stem. The aphid's population in each rice plant phase can be seen in Table 2. The number of aphids in the vegetative phase (1184 individuals) is higher than the generative phase ( 882 individuals). In the vegetative phase, $R$. rufiabdominale (838 individuals) was more founded than $T$. nigriabdominalis (346 individuals) and otherwise, in the generative phase, $T$. nigriabdominalis (645 individuals) was more dominant than $R$. rufiabdominale (237 individuals).

The Aphids population was found in dry vertisol soil type of 2066 individuals. According to Shepard [13], the aphid population that lives on plant roots is higher in laterite soil than muddy or sandy soils, and dominated by $R$. rufiabdominale. Aphid $R$. rufiabdominale has a wider host range than $T$. nigriabdominalis. The aphid can be found in other Poaceae plants such as cogon grass (Imperata cylindrical) [14]. In addition to the roots of plants, $R$. rufiabdominale also live in leaves, stems, and flowers of plants [15].

The population is more often found in the vegetative phase of rice which has not been panicle, because in the vegetative phase the soil is still loose and dry whereas conditions. The generative phase after harvesting the soil is dense and clayed. Aphids found at a depth of approximately $2-5 \mathrm{~cm}$ from the base of the roots on less dry soil is too dense, while in a slightly clayed soil aphids found it at a depth of 7-10 cm from the root base.

The symptoms are inflicted from the aphid's activities that the plant has a yellowish colour and growth decreases. When plants are uprooted, aphids population can be found. The damage caused by adult and nymph activities in the roots, by sucking the plant's root fluid. Aphid feeding activities in rice plants cause changes in leaf colour when hatching and severe attacks during the sapling stage [5]. The same thing was stated
[13], that the aphids in the root sucking up plant fluids can cause plants to turn yellow.

\section{CONCLUSION}

Aphids root rice $R$. rufiabdominale and $T$. nigriabdominalis have different morphological characteristics and distribution areas. R. rufiabdominale can be found at altitudes above 1,000 $\mathrm{m}$ a.s.l., whereas T. nigriabdominalis was founded below $1,000 \mathrm{~m}$ a.s.l. Both species have the same host range on several rice varieties in West Java.

\section{REFERENCES}

[1] K.S. Pike, L. Boydston, D. Allison. Alate aphid viviparae associated with small grains in North America: a key and morphometric characterization. J. Kansas Entomol. Soc. 63 (1990) 559-602.

[2] D. Kindler, L. Hesler, N. Elliortt, K. Shufran, T. Springer. Cereal and grass hosts of the rice root aphid, Rhapolosiphum rufiabdominalis (Sasaki), and a description of an efficient greenhouse rearing techniques. J. Agric. Urban Entomol. 21 (1) (2004) $51-59$.

[3] D. Noordam. Aphid of Java, Aphidini (Homoptera: Aphididae). Leiden, National Naturhistorisch Museum, 2004.

[4] L. G. E. Kalshoven, J. V.D. Vecht, De Plagen Van De Cultuurgewassen in Indonesie, Deel 1, Bandung, NV Uitgeverij W, Van Hoeve, 1950. 
[5] M. D. Pathak, Z. R. Khan. Insect pests of rice. Manila (PHI), International Rice Research Institute, 1994.

[6] E. Galli, G. C. Manicardi. Cytogenetic analysis on the gall generation of two aphid spesies: Tetraneura nigriabdominalis and T. ulmi. Dipartimeno di Biologia Animale. University di Modeno. Italy. Caryologia. 51 (3-4) (1998) 235-243.

[7] K. Saito, B. Linquist, K. Keobualapha, T. Phanthabon, T. Shiraiwa, Hone. Cropping intensity and rainfall effects on upland rice yields in Northern Laos. J. Plant Soil. 284 (2006) 175-185. DOI: https://doi.org/101007/s11104-006-0049-5.

[8] S. Modic, J. Razinger, G. Urek. Tetraneura (Tetraneurelia) nigriabdominalis (sasaki) gallforming aphid found maize roots in Slovenia. J. Acta Entomol. Slovenica. 20(2) (2011) 147-152.

[9] . L. Blackman, V. F. Eastop. Aphids on the World's Crop: An Identification and Information Guide. London, Natural History Museum, 2000.

[10] P. Van der Goot. 1917. Zur Kenntnis Der Blattlause Java's. Contributions à la faune des Indes Néerlandaises. 1(3) (1917) 1-301.

[11] R. L. Blackman, V. F. Eastop. Aphids on the World's Herbaceous Plants and Shrubs. Chichester, John Wiley \& Sons, 2006.

[12] C. Favret, Aphid species file. http://aphid.speciesfile. org. 29 October 2019.

[13] B.M. Shepard, A. T. Barrion, J. A. Litsinger. Rice feeding insect of Tropical Asia. Manila, International Rice Research institute, 1995.

[14] Y. Maharani, P. Hidayat, A. Rauf, N. Maryana. Aphids on weeds in farmlands in West Java and its identification key. Indonesian Journal of Entomology. 15(2) (2018) 74-84.

[15] Y. Maharani, Species Description and Development of Aphid Identification Key (Hemiptera: Aphididae) in West Java, Ph.D. Thesis, IPB University, 2018. 